\title{
Leaks in Spending ${ }^{1}$
}

Josephine Turner ${ }^{2}$

\section{Do You have a Leaking Budget?}

Do you never seem to have enough money to buy the things you would like for your family? Do you ever wonder why your hard-earned dollars buy so few things? And, do you sometimes get little satisfaction from the things you buy?

If you can answer yes to any one of these questions, you may have a leak in your budget. Leaks in your budget mean you are spending money without knowing where it is going. This can be a serious problem. It can threaten your financial security. Although it is unlikely that you and your family have everything you want, stopping leaks in your budget can help you get more of the things you want and need.

Budgets leak for many reasons. Learning to recognize some of the reasons may help you plug the leaks.

\section{Do You Plan How You Spend Your Money?}

Planning can be simple, well worth the effort, and can make your dollars buy exactly what you need. Planning will help you spend your money wisely rather than letting it disappear.

Design a family spending plan that will provide for current spending, savings, and short- and long-term goals. Write down the amount of money you have to spend in one month. Then write down what must be bought within this time. Once you have set aside enough for the necessities, you can decide how to save for the other things you want (goals). With careful planning, you can get many of these things.

\section{Do You Keep Meaningful Records of Where Your Money Goes?}

Records show where and how your money is being used. From them, you can see where you are overspending and become aware of your poor buying habits. Records help you decide if you should keep using your present spending plan or make changes.

Your records may show, for example, that you are spending \$150 a month at the beauty shop. Is the satisfaction you get from this expense as great as what you might get from a color television you could be saving for? This is something you must decide.

Remember, spending is a leak only if the spender is surprised at the amount being spent and feels that it is not worth the money.

\section{Do You Understand How Family Characteristics Affect Spending?}

Different families have different attitudes about the purpose of money. Some see money as a way to bring themselves power or prestige. Others may save, enjoy, share, bribe, reward, or influence others with

1. This document is FCS5244, one of a series of the Department of Family, Youth and Community Sciences, Florida Cooperative Extension Service, IFAS, University of Florida. Publication: December 2002. Reprinted with permission from the Alabama Cooperative Extension System (Alabama A\&M and Auburn Universities. Please visit the EDIS Web site at http://edis.ifas.ufl.edu/

2. Josephine Turner, Ph.D., CFP, professor, Family and Consumer Economics, and reviewed by Nayda I. Torres, Ph.D., professor and chair, Department of Family, Youth and Community Sciences, Cooperative Extension Service, IFAS, University of Florida, Gainesville, 32611, and Patricia Goodgame, extension agent II, Volusia County. 
their money. Recognize how the following family characteristics may influence your spending habits.

1. Your family size, ages, sexes. Young families need a good deal of money to settle into their first homes, to start a family and, sometimes, to start a business. Families with teenagers, however, can make the expenses of a beginning family seem small. Spending for boys and girls will differ. Retired couples often have limited needs for material goods. Many single people have homes and are sometimes head of a household. Spending needs change according to situations.

2. Where you live. Climate can influence such expenditures as housing, utilities, and the amount and kind of clothing required. Cost of living is also much higher in some areas than in others.

3. Cultural background. Almost all American families have other nationality backgrounds that reflect different attitudes and beliefs regarding family life-style.

4. Values and goals. The things you buy are based on your values-in other words, what you think is important. For example, is it more important to you to have a comfortable automobile with deluxe features or one that only provides reliable transportation? Is it your goal to send your children to college or to save for a comfortable retirement? Do you prefer new clothes for your family or new furniture for your home?

\section{Do You Recognize Your Personal Weaknesses?}

Leaks are most likely to occur in the weak spots. The following list can help you recognize yours.

Are you a compulsive spender, unable to resist urges to buy things?

Do you spend to reward yourself after you have had a bad day?

Are you unable to resist something in particular, such as shoes?

Do you buy certain products or services because they represent "people of social distinction"?

Do you fail to get the information you need about a product before buying it? For example, refrigerators with the same features may vary as much as $\$ 60$ or more from store to store. Paying a higher price than necessary is a leak. Make a habit of shopping around to compare prices for items and for credit if you plan to buy on time.

Do you think the most expensive is the best? A study showed that the same factory often produces the same quality products but attaches different labels and price tags. Buying the most expensive could mean a leak.

Are you ashamed of your spending limitation? Accept the money you have as a fact of life. Take pride in your ability to stretch your money as far as possible toward buying the kind of life you want. Don't think you have to "keep up with the Joneses." Help your children realize why they can't have all their wants by including them, as they become old enough, in planning your family budget.

\section{Do You Know How To Buy?}

Shopping for goods and services is complicated. There is such a wide variety of products to choose from. This causes many people to fall into poor buying habits. See if you see yourself in any of the following:

1. Buying on impulse. Spur-or-the-moment buying can wreck your spending plan. To avoid impulse buying:

\section{$\checkmark \quad$ Shop with a list}

$\checkmark \quad$ Learn to shop for food as well as for other items. Teach your family to shop too.

$\checkmark$ Ask yourself such questions as "When will I use it?" "Where will I store it?"

$\checkmark \quad$ Always sleep on a decision to make a major purchase. The offer should be just as good tomorrow.

$\checkmark \quad$ Beware of your mood when you shop. If you are tired, you can be easily influenced.

$\checkmark \quad$ Try not to shop if you are in a hurry.

$\checkmark \quad$ Make a long-term spending plan and try to stick with it.

$\checkmark$ Always allow in your budget an amount of money to spend for entertainment.

2. Buying features you will not use. For example, suppose you want to buy a range that will tell the time, start and stop cooking automatically, allow you to bake and broil at the same time, warn you when foods are done, clean the oven automatically, and provide you with a supply of 
hot water. Do you need all these enough to pay extra for them? Added features can be expensive. Be sure they are worth the extra cost.

3. Buying a quality level not appropriate for your use. The quality of a product is measured by its material, design, and workmanship. You can get most products in three quality levels - high, medium, and low. Each level gives you certain degrees of usefulness, durability, and beauty. When buying, do not depend on price and brand name alone for quality. Inspect products when you shop. Learn to recognize the characteristics of different quality levels. High quality has the best materials, design, and workmanship. It may be the best buy for men's suits or work clothes because they will last a long time. Medium quality usually has reliable materials, design, and workmanship and could be the best buy for a child's coat since it will be outgrown in one or two seasons. The best buy for a child's swimsuit may be the lower quality. It has acceptable materials, design, and workmanship and should last the short time it is needed. Think about how you will use the product and then look for the quality level that best meets your needs and fits your pocketbook.

4. Buying things seldom or never used. This does not mean that all things not continually used are poor buys. But, a leak does occur when a product brings little or no pleasure to the owner. Some possible leaks are:

$\checkmark$ Vacuum cleaner attachments that are never taken out of the box.

$\checkmark$ A variety of fishing gear when only the old favorites are used.

$\checkmark$ Large expenditures for faddish clothes that will go out with next year's new styles.

$\checkmark$ A home computer for your children to play video games on and for you to use only to balance your checkbook. A game machine and a calculator can serve the same purposes with less cost and frustration.

5. Buying the wrong form, size, or quantity. Planning your spending will help you decide the form, size, or quantity of merchandise you need. Time, energy, and money are wasted when items are bought in too large or too small quantities. This is especially true in food buying. Buying too small an amount means more frequent shopping. Buying too much can result in waste or missing an opportunity to take advantage of special sales.

6. Buying things that take too much upkeep. Non-washable, light-colored fabrics mean extra dry cleaning costs.

Good buying means learning the marketplace, learning about quality, and then deciding what you need. It's up to you and your family to get your money's worth.

\section{Do You Get Full Life From Your Purchases?}

Little is gained when money saved through good shopping practices is lost through poor use and care of a purchase. Find out how to care for the things you buy. Read the booklet or tags that come with the items. If they are not included with the item, ask a salesclerk or write the manufacturer. Prolong the life of the product with proper care. When a purchase lasts longer, your money does, too.

\section{Do You Use Advertising To Your Advantage?}

Advertising is one way to learn what is available, where to buy it, and how much it costs. However, advertising is designed to persuade you to buy. Be sensible. Study and compare advertisements.

\section{Do You Fully Understand Credit?}

It costs more to buy on credit than with cash. The cost of credit depends on the kind of credit account, how much you need, and how long it is needed. Today, you can shop for credit as well as other goods and services. Carefully study and understand the terms before signing a credit contract.

\section{Do You Anticipate Your Needs?}

People can anticipate some of their needs such as gifts, next season's clothing, and replacing worn-out appliances. Take advantage of out-of-season sales. Buying when the price is right can increase your buying power.

\section{Advantages of Plugging the Leaks In Your Budget}


Family peace and harmony rather than money worries and tension.

$\star$ Knowing where you want to go and how to get there rather than feeling you can't get ahead.

Realistically expecting what is possible with what you have rather than living in a dream world.

$\star$ Controlled spending for goods and services that brings the family closer to its goals rather than unthinking, unwarranted spending.

$\star$ Find the leaks in your spending. Try to understand what you do to cause them. Working together to stop the leaks will help direct your dollars where you want them to go.

\section{Resources}

For more information, contact your county Extension office.

Look in your telephone directory under your county's name to find the number.

Visit the World Wide Web at:

http://www.ifas.ufl.edu/extension/index.htm which gives you a county by county listing, and takes you to each county's home page 